\title{
Financial Performance of Village-Owned Enterprises: Case in Blitar Regency, East Java, Indonesia
}

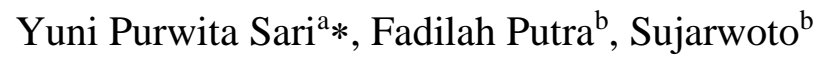 \\ ${ }^{a}$ Regional Development Planning Agency of Blitar Regency, Indonesia \\ ${ }^{a}$ Department of Public Administration, Universitas Brawijaya, Indonesia
}

\section{ARTICLE INFORMATION}

\section{Article history:}

Data submission : 20 May 2020

$1^{\text {st }}$ revision: 12 November 2020

Accepted: 18 November 2020

Available online: 25 November 2020

Keywords: Financial performance; Village-Owned Enterprises; affecting factors

\begin{abstract}
Villages have many assets and potentials. Through Village-Owned Enterprises (VOEs), business entities owned by villages, the village assets and potentials could be managed well for the greatest welfare of the village community. As public enterprises, VOEs are expected to play an important role in mobilization of resources and they can do so if they are financially viable. Therefore, financial performance is a vital element for Village-Owned Enterprises (VOEs) sustainability. Using a multi-method design, this research aims to examine the growth of financial performance of VOEs in Blitar Regency from 2015 to 2019 and to explore factors that affect the financial performance of VOEs in Blitar Regency from 2015 to 2019 . The results discover that, in general, the financial performance of VOEs in Blitar Regency did not show any significant growth. Out of 85 observed VOEs, 74 of them did not go up from their previous level. However, there are VOEs whose financial performance are increase and decrease, which are five and six VOEs respectively. In addition, human resources, support from the Village Government, and VOE's ability to see business opportunities that exist in accordance with community needs and the potential of the village become the factors that affect the financial performance of Village-Owned Enterprises (VOEs). These factors should be considerations for policymaker and other stakeholders in setting appropriate programs or activities intended to enhance the development of VOEs, which will eventually, contributes to the village development.
\end{abstract}

2020 FIA UB. All rights reserved.

\section{Introduction}

Decentralization has undoubtedly gained popularity within the last two decades (Work, 2002). It is estimated that 80 percent of developing countries including the transitional economies of Eastern and Central Europe are experimenting with some form of decentralization (Furtado, 2001). The difficulties in administering and managing development programs efficiently and effectively under centralized planning caused many developing countries to decentralize responsibility for socioeconomic development planning and management to the local agencies and local government (Firman, 2009).

Grindle argues that decentralization is intended to make local governments empowered and more responsive to local needs, and not otherwise. It aims to minimize dependence on a central government, to improve accountability, to institutionalize change, and to encourage economic development (Grindle, 2007 in Firman, 2009 : p.145). People believed that the local development can be triggered by the local autonomy. In addition, local autonomy also can encourage the local governments and local communities to initiate necessary actions and regulations for their own benefits (Firman, 2009).

Indonesia is one of countries applying decentralization radically. In 2000, Indonesia replaced the centralized governance system and prior development planning with the decentralization program. This reform gives greater authority, political power, and financial resources to local governments (Nasution, 2016). Law No. 32 of 2004 gives authority to local governments to execute a wide range of 
responsibilities in areas such as health, education, public works, environment, communication, transport, agriculture, manufacturing industry and trade, capital investment, land, cooperatives, labor force, and infrastructure services. In addition, Law No. 23 of 2014 concerning the Local Government itemize the responsibilities of the subnational governments.

The issuance of Law Number 23 of 2014 concerning Local Government, as a revision of Law Number 32 of 2004, became a momentum for changes in policy direction related to the implementation of decentralization and local autonomy (Center for Decentralization and Local Autonomy Studies, 2015). In its development, Law No. 32 of 2004 was finally broken down into three major substances, i.e.: the implementation of the local government itself (through Law No. 23 of 2014), local head elections (Law No. 22 of 2014, replaced with Law No. 1 of 2015 which part of the main contents amended in Law No. 8 of 2015), and villages (Law No. 6 of 2014).

Decentralization, as a form of administrative reform, brought support for the local government to improve their local development by optimizing their potentials. It also gives benefit to villages, where previously they have less priority in socioeconomic development. The issuance of Law No. 6 of 2014 is the result of seven years hard work of village activists and politicians in the parliament in formulating rules that underlining a renewal need in the implementation of village governance (Center for Decentralization and Local Autonomy Studies, 2015). The Law ensure that villages are able to become the main agents of national development. This is in line with the text of "Nawacita", the vision of President Jokowi's government, regarding the direction of national development starting from the periphery, which is the villages.

The 2014 Village Law gives autonomous authority to the village to regulate the household of its own government. This law is an effort to make the village no longer as an object of development, but as the subject of development, which means that the village becomes the executor for its own development. Villages are invited to manage all existing resources in their territory to support the implementation of development and public services.

Villages have many potentials that can be managed for the welfare of village community. Village-Owned Enterprise (VOE) is one of ways that can be utilized to manage village potentials. This is in line with the mandate of Law No. 6 of 2014 concerning Village. In Village Law article 90, it states that the government gives support to VOEs by giving them more priority in managing resources in the village (Law of Republic of Indonesia Number 6, 2014). VOE is expected to be the center for a healthy and productive economic turnover that can provide benefits to rural communities.

The implementation of village autonomy can be seen from the independency of a village through the existence of Village-Owned Enterprise (VOE), a business entity which entire or part of the capital is owned by the village through the direct participation originating from village assets that are separated to manage assets, services and other businesses for the greatest welfare of the village community (Law of Republic of Indonesia Number 6, 2014). Through the VOE, it is hoped that village is not entirely dependent on subsidies from the government in implementing the development. VOE can be an alternative that provides additional funds for village finance (Risadi, 2012). VOE is also useful for managing the assets and wealth of the village so that it can be utilized as much as possible for the welfare of the village community.

VOE is a pillar of economic activity in the village that functions as a social institution and a commercial institution (http://presidenri.go.id/, 2016). VOE as a social institution must side with the interests of the community through its contribution in the provision of social services. This is in line with the objective of establishing a VOE in general, as stated in the Law No. 6 of 2014 concerning the Village.

The Ministry of Village, Underdeveloped Regional Development and Transmigration conveys that the role of VOEs is to improve the economy of rural communities (Setiawan, 2018). Furthermore, VOEs also have an important role in changing the level of welfare of rural communities (Setiawan, 2018). There are many numbers of VOEs have succeeded in gaining huge profits and being able to improve the economy of their people. The creative and innovative VOE can bring huge benefits for the village.

It is important for VOEs to improve their performance, in order to increase the growth of their organization. Growth is a way to make the organization in the future better than in the present time (Robbin, 1994 in Wirda, 2008). According to Robbin (1994), there are four reasons of why organizations seek the growth, i.e.: 1) bigger is better; 2) growth increases the chance of survival; 3) growth is a synonym of effectiveness; and 4) growth is power (Wirda, 2008). Therefore, one step that can be taken to measure the organization growth is by examining the growth of its financial performance.

Financial performance is a subjective measure of the accountability of an entity for the results of its policies, operations and activities quantified for an identified period in financial terms (Public Sector Accounting Standards Board's (PSAB) Conceptual Framework Task Force, 2012). In the public sector, the nature of financial performance is a function of what the public sector entity is held accountable for accomplishing in financial terms in the identified period. Assessment of financial performance is one way that can be done by the management in order to fulfill its obligations to funders and to achieve the goals set by the organization.

Financial performance is an analysis conducted to see the extent to which an enterprise has carried out the rules of financial implementation properly and correctly (Resti, 2019). This analysis also aims at assessing management's performance and knowing management's 
success in managing VOEs so that they can be improved in the future.

This research aims to examine the growth of financial performance of Village-Owned Enterprises (VOEs) in Blitar Regency between 2015 and 2019, and to explore factors that affect the financial performance of Village-Owned Enterprises (VOEs) in Blitar Regency between 2015 and 2019.

The result of this research is important, because it will give better understanding and input for not only the Local Government of Blitar Regency but also other stakeholders of VOEs' governance regarding the appropriate strategies and programs to enhance the VOEs' development.

\section{Theory}

Village-Owned Enterprises (VOEs or "BUMDes" / "Badan Usaha Milik Desa" in Indonesian language) are enterprises founded and owned by the village government. These enterprises are intended to improve the welfare of village community. In Law No. 32 of 2004 concerning Local Government stated that, VillageOwned enterprise was established in the context of increasing Village Income. As one of the economic institutions operating in rural areas, a VOE must have differences with other economic institutions so that the existence and performance of VOE can contribute significantly to improve the welfare of the villagers. In addition, VOE can lessen the capitalistic business system practice in the countryside that can lead to disruption of the values of social life.

According to Government Regulation Number 43 of 2014 concerning Villages, Village-Owned Enterprises are business entity that all or most of its capital is owned by the village through direct participation from village assets which are separated in order to manage assets, services, and other businesses for the greatest welfare of the village community. The purposes of establishing VOEs are (Law of Republic of Indonesia Number 6, 2014):

1) Increasing the village economy;

2) Optimizing the village assets to be beneficial for the welfare of the village;

3) Increasing community efforts in managing the economic potential of the village;

4) Develop a business cooperation plan between villages and/or with third parties;

5) Creating market opportunities and networks that support the general need services of citizens;

6) Open employment;

7) Improving community welfare through improving public services, growth and equitable economic village;

8) Increasing the income of the village community and Village Original Income.

The Village Government can establish VOE, which agreed through the Village Council. The agreement as result of Village Council becomes a guide for the Village Government and the Village Consultative Body to set the Village Regulation concerning the VOEs' Establishment.

As a business entity, it is important to measure the financial performance of Village-Owned Enterprises (VOEs). Financial performance is important to assess the management performance, to find out the success of management in managing the VOEs, and to evaluate deficiencies in VOEs management (Resti, 2019).

One of the financial performance appraisals can be done with financial ratio analysis (Resti, 2019). Financial ratios are numbers obtained from the results of a comparison of one financial statement account with another account that has a relevant and significant relationship. The use of financial ratio analysis in the public sector has not been done so much, so that in theory there is no agreement regarding the name and rules of measurement (Halim, 2007). However, in the context of transparent and accountable regional financial management, financial ratio analysis of public sector financial statements needs to be carried out, even though the accounting rules in public sector financial statements differ from those of private organizations.

Scholars try to assess the financial performance of VOEs with several approaches. CAMELS, an international rating system used by regulatory banking authorities in rating the financial institutions, has often been adopted by researchers to measure the financial performance of VOEs. Originally, this rating system is used to evaluate the bank level of risk and overall condition in six aspects, i.e. capital adequacy, asset quality, management efficiency, earning quality, liquidity, and sensitivity to market risk (Kagan, 2020). In Indonesia, this method was adopted to assess the soundness level of public banks, based on the Regulation of the Bank of Indonesia No. 6/10/PBI/2004 dated April 12, 2004 concerning the Bank Soundness Rating System. With some modifications, some researchers adopted the CAMELS rating system to assess the financial performance of banking VOEs (Mandra, 2013; Hartini et al., 2016). They used several financial ratios which proxy's assessment of the capital adequacy, asset quality, management efficiency, earning quality and liquidity to assess financial performance of VOEs, particularly for banking VOEs.

Another study performed by Sutardi et al. (2017) utilized ratio analysis to measure the financial performance of VOE in the process of credit distribution. This study focuses on banking VOEs only and use six ratio analysis, as follows: 1) Loan to deposit ratio; 2) Asset to loan ratio; 3) Interest margin on loan ratio; 4) Rate of return on loan ratio; 5) Capital ratio; and 6) Credit risk ratio.

Since there are other types of VOE besides banking VOE, i.e., serving VOE, brokering and renting VOE, trading VOE, and holding VOE, other researchers consider utilizing a different approach to measure VOE's financial performance, which is financial ratio analysis (Afrijal and Ramadhani, 2016; Pebriyanti et. al., 2017). They argue that VOE has characteristics similar to Small and Medium Enterprises (SMEs), so 
they use liquidity ratios, solvency ratios, profitability ratios, and activity ratios, where financial ratios aforementioned are usually used to assess the financial performance of SMEs. This method was adapted based on the Regulation of the Minister of Cooperatives and Small and Medium Enterprises of the Republic of Indonesia No. 06/Per/M.KUKM/V/2006. Afrijal and Ramadhani (2016) and Pebriyanti et. al. (2017) used: 1) Current ratio to assess the liquidity; 2) debt to asset ratio to assess the solvability; and 3) ROA to assess the profitability. While for activity aspect, Afrijal and Ramadhani (2016) used ratio of total asset turn over.

While the Local Government of Blitar Regency, in collaboration with Faculty of Agriculture of Brawijaya University, measuring the performance of VillageOwned Enterprises (VOEs), in aspects of asset development, assets utilization, productive asset quality, profitability, and management (Collaboration of Department of Community and Village Empowerment of Blitar Regency with Faculty of Agriculture of Brawijaya University, 2017). Since there are many kinds of financial ratios that can be used to measure the financial performance of Village-Owned Enterprises (VOEs), a study can utilize financial ratios that appropriate with its purpose and the availability of the data. In this study, we use five financial ratios, i.e. Cash Turnover Ratio, Working Capital to Total Asset Ratio, Net Profit Margin, Return on Asset (ROA), and Total Asset Turnover Ratio, to measure the financial performance of Village-Owned Enterprises (VOEs) in Blitar Regency.

\section{Research Method}

The design of this study is multi-method design, this is the conduct of two or more research methods, each conducted rigorously and complete in itself, in one project (Morse, 2003). This study involves both quantitative and qualitative design which is consist of two-phases. In the first phase, quantitative design is adopted to examine the financial performance of Village-Owned Enterprises (VOEs) in Blitar Regency between 2015 and 2019. The results of the first phase then will be used to plan the second phase. In the second phase, the qualitative approach is employed to explore factors that affect the financial performance of VillageOwned Enterprises (VOEs) in Blitar Regency.

This first phase of the study is intended to examine the growth of financial performance of Village-Owned Enterprises (VOEs) in Blitar Regency between 2015 and 2017. Financial ratios are used to assess the financial performance. Instead of describing the results of VOEs financial performance, this phase will examine the growth of VOEs financial performance from 2015 to 2019 , or in other word its sustainability on financial performance.

The second phase of this study is intended to explore factors that affect the financial performance of Village-Owned Enterprises (VOEs) in Blitar Regency between 2015 and 2019. The result of the first phase become the base to plan the second phase which is conducted through the qualitative approach.
The informants for individual interviews are chosen using stratified random sampling technique. Six VOE's managers who represent three VOEs with increasing performance and three VOEs with decreasing performance are chosen as samples for semi-structured interview, since they have a broader understanding regarding the governance of VOEs. This research is conducted in Blitar Regency, East Java Province, Indonesia. Blitar Regency is a rural area consists of 22 sub-districts, which is divided into 28 urban-villages and 220 villages. The rural characteristics, potentials of the villages, and the VOEs' performance are factors considered in choosing Blitar Regency as research location.

\section{Results}

\subsection{Financial Performance of Village-Owned Enterprises in Blitar Regency}

The history of VOEs in Blitar Regency was started in 2008. There are three first VOEs established in 2008, i.e.: 1) VOE Sejahtera, Kerjen Village, Srengat SubDistrict; 2) VOE Mitra Usaha, Bendorejo Village, Udanawu Sub-District; and 3) VOE Nuju Mandiri, Selorejo Village, Selorejo Sub-District. All of them starting the VOE business with saving and loan business unit.

In 2011, the Regent of Blitar released Regent Regulation No. 8 of 2011 concerning General Guidelines for Establishment of Village-Owned Enterprises (VOEs). This results in the establishment of 170 VOEs in 2011. However, not all villages were ready to running the VOE business units. Most of VOEs only exist without any activity.

In 2015, based on data from the Department of Village and Community Empowerment of Blitar Regency, the number of VOEs reaches 220. This means that each village has one VOE. This year, collaborating with Brawijaya University, the Local Government conducted the first VOE Mapping, as one of efforts in enhancing VOEs' development. The VOE Mapping found that there are many VOEs whose management structure is unclear, administrative problems are not well organized, and the business units owned do not work well.

To foster the development of VOE, the local government takes the following steps:

1) Conducting the VOE Mapping regularly, which is done biennially;

2) Make a coaching program in accordance with the categorization of the soundness of VOEs;

3) Business Plan training and VOEs business development;

4) Financial administration training;

5) Establishment of VOEs Clinic as a consultation center (by the Provincial Government);

6) Collaborating with university as partners in the development of VOEs in Blitar Regency, in this case with Brawijaya University. 
Some VOEs even have proud achievements at provincial level and even at national level. One of the VOEs in Blitar Regency, VOE Maju Makmur located in Minggirsari Village. VOE Minggirsari has been selected several times as the best national VOE because they manage businesses professionally, both savings and loans and the development of farming businesses that have a turnover of hundreds of millions per month (http://presidenri.go.id/, 2016). In 2018, VOE Makmur Abadi of Bendosari Village, Sanankulon Sub-District, won the third place of best VOEs in East Java Province. VOE Makmur Abadi runs a milk-processing unit, which process milk produced by dairy farmers in this village into ready-to-drink milk. Besides that, VOE Makmur Abadi also runs other business unit, that is saving and loan, organic fertilizer processing, kiosk rental, milkprocessing educational tourism, and business incubator.

Out of 220 VOEs in Blitar Regency, there are only 85 VOEs have the complete data that can be used for further analysis. The financial ratio analysis is performed on 85 VOEs to examine the VOEs' financial performance. Then, those VOEs are classified into three classes, i.e. healthy (FPscore $>=6.5$ ) quite healthy $(5<=$ FPscore $<6.5)$, and unhealthy (FPscore $<5)$, based on their composite score of financial performance. The financial performance classification is adopting the classification of VOE's health level by the Local Government.

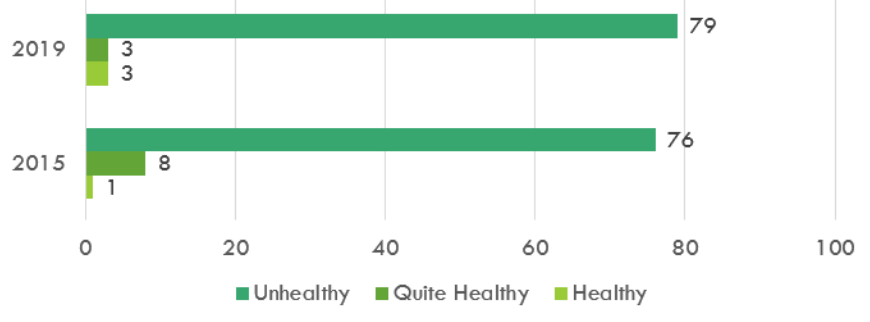

Figure 1 Comparison of VOEs' Financial Performance between 2015 to 2019

After getting the score of financial performance and classify it based on its health level, the next step is determining the growth of financial performance from 2015 to 2019. The determination is based on these assumptions:

- Increasing performance: for VOE that experienced improvement in the classification of financial performance from 2015 to 2019;

- Decreasing performance: for VOE that experienced drop in the classification of financial performance from 2015 to 2019 ;

- Constant/no-change performance: for VOE that have the same class in the classification of financial performance from 2015 to 2019.

Based on the assumptions aforementioned, we found that only a few numbers of VOEs move from their previous class. Figure 1 shows the comparison of VOEs' financial performance between 2015 and 2019. In general, there is no significant growth of VOEs' financial performance. Out of 85 VOEs, 74 of them are at the same class in 2015 and 2019. It does not mean that those VOEs did not gain any improvement in their financial performance. Their financial performance score might be slightly increased, but it does not make them changed class status from 2015 to 2019. On the other hand, there are five VOEs have significant improvement financial performance and six VOEs with drop financial performance, as shown in Figure 2.

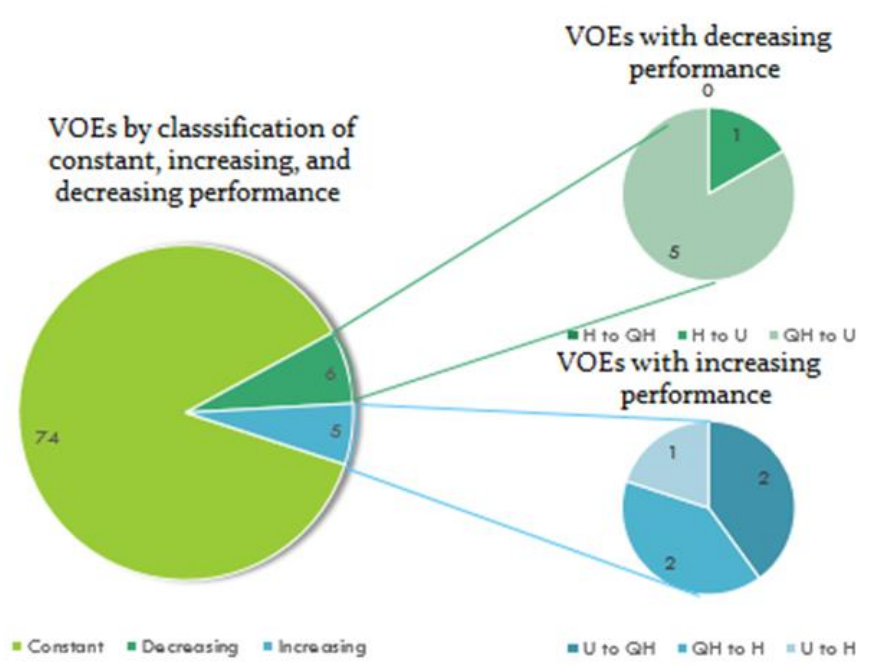

Figure 2 Proportion of VOEs with Increasing and Decreasing Score of Financial Performance

\subsection{Factors Affecting Financial Performance of Village-Owned Enterprises}

The results of the first phase of the study, which is result of financial performance analysis, become the reference in the second phase of the study, which is exploring factors that affect the financial performance. However, before conducting the investigation directly to the research location, first we analyzed the management aspects of VOEs that might affecting the financial performance of VOEs.

There are six management aspects analyzed to find out whether they affect the financial performance or not, i.e. legality, articles of association and bylaws, secretariat office, signboard, operational implementer, and contribution of VOE to the Village Government. From those management aspects, we look for whether there is a relationship between these aspects with VOE's financial performance position. However, there is no clear tendency on which to draw conclusion. So, we conducted a detailed interview for the case of improved and grew worse VOEs to find the determinants of change. We conduct semi-structured interviews and field surveys towards three VOEs with increasing performance and three VOEs with decreasing performance. The field survey was conducted from March 3rd to April 3rd, 2020, at six VOEs located in five sub-districts of Blitar Regency. 
Table 1 Location of Field Survey

\begin{tabular}{llll}
\hline No. & \multicolumn{1}{c}{ VOE } & \multicolumn{1}{c}{$\begin{array}{c}\text { Location } \\
\text { (Village, Sub- } \\
\text { District) }\end{array}$} & $\begin{array}{c}\text { Description } \\
\text { of VOE's } \\
\text { Performance }\end{array}$ \\
\hline 1. & Al Hikmah & Besuki, Udanawu & Increase \\
\hline 2. & Sari Mulyo & $\begin{array}{l}\text { Bendosari, } \\
\text { Kademangan }\end{array}$ & Increase \\
\hline 3. & Bina Usaha & $\begin{array}{l}\text { Serang, } \\
\text { Mandiri }\end{array}$ & Increase \\
\hline 4. & Sumber Urip & Sawentar, Kanigoro & Decrease \\
\hline $\mathbf{5 .}$ & Srikandi & Kuningan, Kanigoro & Decrease \\
\hline 6. & $\begin{array}{l}\text { Sumber } \\
\text { Rejeki }\end{array}$ & Kendalrejo, Srengat & Decrease \\
\hline
\end{tabular}

In the term of factors that affect the financial performance of VOEs, we found varies answer from the informants and summarize them, as follows:

1) Supporting factors:

a) Human resources:

- The capability of VOE human resources, especially the director;

- The experience in business and management

- The intention and will from the VOE employees to develop their VOE

- Participation of VOE in the VOE coaching program from the local government and the application of the results of the coaching program in their VOE

b) Support from the Village Government

- A harmony between the VOE and Village Government (Village Head and Village Consultative Body)

- Capital support, in form of village funds budgeted for VOE capital that was given to the VOE annually.

- Village assets that can be managed for the VOE development (building, means of transportation, etc.)

c) VOE's ability to see business opportunities that exist, in accordance with community needs and the potential of the village

- Some villages are blessed with the advantages from the geographical location, fertile soil, good socio-economic condition, etc. The others are not as lucky as those villages.

- Some VOEs are success in running their business because they can see the business opportunity from the villagers needs (clean water, venture capital loans, village market, etc.)

2) Hindering factors:

a) Lack of Human Resource Capacity

- The VOE employees were appointed by the Village head only by looking at their good relations, not based on their ability to manage VOE.

- VOE management cannot be held responsible for the use of $\mathrm{VOE}$ venture capital.

- There are many VOEs that have changed management, and the new management is still trying to solve the problem left by the old management. Therefore, the employees of the new management are reluctant in running the VOE business.

- Being the VOE employees are only their side job, therefore they lack of enthusiasm in running the VOE business.

b) Less Support from the Village Government

- A disharmony between the VOE and Village Government (Village Head and Village Consultative Body)

- Less (and even "no" in some VOEs) capital support from the Village Government. Many Village Government only gave the capital support at the at the beginning of the formation of VOE.

c) VOE's inability to see business opportunities that exist, in accordance with community needs and the potential of the village

- VOEs located near to the city have more business competitors (from the private sector).

- Villagers of the village located near to the city can fulfill their needs provided by the private sector, therefore there is less business opportunity that can be taken by the VOEs.

In general, human resources, support from the village government, and VOE's ability to see business opportunities that exist, in accordance with community needs and the potential of the village are factors that affect the financial performance of VOE.

\section{Discussion and conclusion}

This research aims to examine the growth of financial performance of Village-Owned Enterprises (VOEs) in Blitar Regency between 2015 and 2019, and to explore factors that affect the financial performance of VillageOwned Enterprises (VOEs) in Blitar Regency between 2015 and 2019.

The financial performance of VOEs in Blitar Regency, in general, did not show any significant growth. Out of 85 observed VOEs, 74 of them did not go up from their previous level. However, there are VOEs whose financial performance are increase and decrease, which are five and six VOEs respectively.

Human resources, support from the Village Government, and VOE's ability to see business opportunities that exist in accordance with community needs and the potential of the village become the factors that affect the financial performance of Village-Owned Enterprises (VOEs). 
Based on conclusions, the policy maker should consider factors that affect the financial performance in setting the programs addressed to enhance the growth of Village-Owned Enterprises (VOEs), that is: human resources, support from the Village Government, and VOE's ability to see business opportunities that exist in accordance with community needs and the potential of the village. This study employs selected financial ratios to examine the financial performance of VOEs due to the various business units that exist and the availability of secondary data. Other financial ratios can be used to be more focus on one type of business unit and if the data are available.

This study only focuses on the VOEs' financial performance, without considering other aspects. To better understand the performance of VOEs thoroughly, the future studies should consider to utilize other method (e.g. balanced scorecard).

\section{References}

Center for Decentralization and Local Autonomy Studies. (2015). Telaah Isu-isu Strategis Desentralisai dan Otonomi Daerah. (M. I. Nasution, Ed.) Jakarta: Pusat Kajian Desentralisasi dan Otonomi Daerah Lembaga Administrasi Negara.

Collaboration of Department of Community and Village Empowerment of Blitar Regency with Faculty of Agriculture of Brawijaya University. (2017). The Mapping of Village Owned Enterprises (VOEs) of Blitar Regency 2017. Blitar: Department of Community and Village Empowerment of Blitar Regency.

Firman, T. (2009). Decentralization Reform and LocalGovernment Proliferation in Indonesia: Towards a Fragmentation of Regional Government. RURDS Vol. 21, No. 2/3, July/November 2009, 143-157. doi:10.1111/j.1467-940X.2010.00165.x

Furtado, X. (2001). Decentralization and Capacity Development: Understanding the Links and the Implications for Programming. CIDA Policy Branch, August 2001.

Halim, A. (2007). Akuntansi Sektor Publik : Akuntansi Keuangan Daerah. Jakarta: Salemba Empat.

http://presidenri.go.id/. (2016, April 28). Memajukan Ekonomi Desa Melalui BUMDes. Retrieved September 2, 2019, from http://presidenri.go.id/: http://presidenri.go.id/program-prioritas2/memajukan-ekonomi-desa-melaluibumdes.html

http://www.berdesa.com/. (2018, Nopember 29). Berita Desa: Pentingnya Mengetahui Potensi Ekonomi Desa. Retrieved from berdesa: http://www.berdesa.com/pentingnyamengetahui-potensi-ekonomi-desa/
Law of Republic of Indonesia Number 6. (2014). The Village.

Morse, J. M. (2003). Principles of Mixed Methods and Multimethod Research Design. In A. Tashakkori \& C. Teddlie (Eds.), Handbook of mixed methods in social and behavioural research, 189-208.

Nasution, A. (2016). Government Decentralization Program in Indonesia. Asian Development Bank Institute. Tokyo: ADBI Working Paper 601. Retrieved from http://www.adb.org/publications/governmentdecentralization-program-indonesia/

Public Sector Accounting Standards Board's (PSAB) Conceptual Framework Task Force. (2012). Measuring FInancial Performance in Public Sector Financial Statements. Conceptual Framework Consultation Paper 2.

Resti, A. (2019, April 23). Pengendalian Internal dengan Menilai Kinerja Keuangan BUMDes. Retrieved April 24, 2019, from https://bumdes.id/: https://bumdes.id/2019/04/pengendalianinternal-dengan-menilai-kinerja-keuanganbumdes/

Risadi, A. A. (2012). Badan Usaha Milik Desa. Jakarta: Dapur Buku.

Setiawan, R. (2018, July 24). Kemendes Sosialisasikan Pentingnya BUMDes agar Desa Mandiri. Retrieved September2 2, 2019, from https://finance.detik.com/:

https://finance.detik.com/berita-ekonomibisnis/d-4131781/kemendes-sosialisasikanpentingnya-bumdes-agar-desa-mandiri

Wirda, F. (2008, April). Managing Organizational Life Cycle. Jurnal Ekonomi dan Bisnis, 3(1), 38-52.

Work, R. (2002). Overview of Decentralization Worldwide: A Stepping Stone to Improved Governance and Human Development. 2nd International Conference on Decentralization Federalism: The Future of Decentralizing States. Manila, Philippines. 